Relations industrielles

Industrial Relations

\title{
Barker, Kathleen and Kathleen Christensen, editors, Contingent Work: American Employment Relations in Transition
}

\section{Isik Urla Zeytinoglu}

Volume 55, numéro 3, 2000

URI : https://id.erudit.org/iderudit/051343ar

DOI : https://doi.org/10.7202/051343ar

Aller au sommaire du numéro

Éditeur(s)

Département des relations industrielles de l'Université Laval

ISSN

0034-379X (imprimé)

1703-8138 (numérique)

Découvrir la revue

Citer ce compte rendu

Zeytinoglu, I. U. (2000). Compte rendu de [Barker, Kathleen and Kathleen Christensen, editors, Contingent Work: American Employment Relations in Transition]. Relations industrielles / Industrial Relations, 55(3), 553-555. https://doi.org/10.7202/051343ar

Tous droits réservés @ C Département des relations industrielles de l'Universite Laval, 2000
Ce document est protégé par la loi sur le droit d'auteur. L’utilisation des services d'Érudit (y compris la reproduction) est assujettie à sa politique d'utilisation que vous pouvez consulter en ligne.

https://apropos.erudit.org/fr/usagers/politique-dutilisation/ 
chômage...), il soutient qu'avant 1995 domine dans le syndicalisme autonome un pragmatisme de type local caractérisant alors les syndicalistes qui y participent comme « réformistes par défaut, au sens où ils s'inscrivent, même sans le dire explicitement, dans le cadre des institutions sociales et politiques existantes, qu'ils entendent améliorer en approfondissant leur caractère démocratique " (p. 183). Par contre, la configuration ouverte par le «Tous Ensemble» de la contestation sociale de type global de 1995 (p. 209), engendre une évolution radicale qui atteint SUD-PTT et plus largement les syndicats qui se créent alors à son image. Dès lors, «avec le maintien d'un lien fort entre des sujets aussi différents que la question salariale, le chômage, la question des femmes, des immigrés, de l'écologie, et, localement, de l'antinucléaire. Plutôt qu'un lieu d'éclatement des liens, le pragmatisme inventif de SUD constitue plutôt le point de départ d'un renouveau syndicalpolitique » (p. 255). Déjà aiguillon et novateur, le syndicalisme autonome se voit, en conclusion, invité par Ivan Sainsaulieu à « chercher des idées, à théoriser et à se saisir des opportunités pour créer des mobilisations qui font date » (p. 273).

Cet ouvrage apporte assurément sa contribution à une meilleure connaissance de la société française en explorant un espace où les tensions et les contradictions n'ont cessé de croître ces vingt dernières années. Tout juste peuton regretter, mais il s' agit certainement ici d'un biais disciplinaire, qu'à la recherche d'une caractérisation de ce syndicalisme autonome, l'auteur ne se soit pas engagé dans une réflexion critique sur les catégories mêmes de la représentation politique. Il aurait ainsi pu établir que la crise de la représentation spéculaire pousse à l'articulation d'une complémentarité entre démocratie représentative et démocratie directe, qu'elle explique la confrontation entre formes fédérées et confédérées, qu'elle interdit désormais aux syndicats, comme aux partis d'ailleurs, de se comporter comme une avant-garde dépositaire d'une « juste » orientation de classe. Dès lors, en soutenant que l'action syndicale ne se réduit pas à la consultation des salariés ou des usagers-citoyens, mais qu'il inclut leur intervention et leur mobilisation dans les modes de décisions, on peut défendre que les SUD et les autres syndicats du G10 participent largement à l'institution imaginaire de la société à travers l'apport fournit au processus de démocratisation des rapports sociaux. Pour l'essentiel, ils stimulent un élément émergent de cette recherche de citoyenneté généralisée qui travaille avec des catégories originales nos sociétés au quotidien.

Patrick Rozenblati Travail et Mobilités-CNRS Université Paris 10

\section{Contingent Work: American Employment Relations in Transition}

edited by Kathleen BARKER and Kathleen CHRISTENSEN, Ithaca, NY: ILR Press, 1998, 350 p., ISBN 0-8014-8405-7 (pbk.: alk. paper) and ISBN 08014-3369-X (cloth: alk. paper).

This is one of the recent additions to books focusing on transitions taking place in American employment relations. The book focuses on contingent work of temporary, self-employed contract, or involuntary part-time work. All chapters, except one, are on the U.S. labour market and the experiences of contingent workers there. Although the focus is on the U.S., there is much to learn from its experiences, particularly for those who are newcomers to this field. One of the important contributions of the book is to bring together thinkers from diverse fields such as anthropology, sociology, social psychology, 
labour economics and business. Thus, the book benefits not only from these diverse ideas but also from the variety of methods used to examine the topic.

Although the editors did not define a thesis, the book was written to answer three major questions: How do workers fare economically, socially, and psychologically in contingent work? How have American corporations utilized contingent work? And what is the role of government in fueling the development of contingent work and, at the same time, providing mechanisms to protect workers in this type of work? In attempting to answer these questions, the editors have organized the book into four sections. The first section gives a general sense of the size of the contingent workforce in the U.S. and its patterns; the second focuses on workplaces and corporate policies; the third section examines the experiences of individuals working in contingent employment showing the human face behind the statistics. The last section covers labour and employment policy in the U.S. and concludes with summary and research questions.

I found the first chapter by Morse, titled "The Peripheral Worker" (1969), as the most important contribution of the book. Although written almost thirty years ago, it is still up to date in its analysis of the peripherality of the contingent work and its interrelationship with demographic characteristics of gender, age, race and national origin. Placing these factors in the historical context of immigration, industrialization and the perception of the 'other, thus outsider' in the U.S. society, this chapter shows that not much has changed in the last thirty years. In particular, in contemporary U.S. society, contingent work is still covered by females, young and old, or non-Whites or recent immigrants that are different from the mainstream Americans. This article thus reaffirms how easily most of the historical context is forgotten in contemporary studies on contingent work.

The next two chapters in Part 1 attempt to define and enumerate contingent work and give the gender composition of these work arrangements by using a special supplement to the Current Population Survey data (in Chapter 2 by Cohany, Hipple, Nardone, Polivka and Stewart) and the Survey of Income and Program Participation data (in Chapter 3 by Spalter-Roth and Hartmann). Both chapters provide the numbers to make sense of the contemporary trends and also show the difficulties in the conceptualization and counting of contingent work. Chapter 2 gives recent data for the variables discussed in Morse's work. Chapter 3 shows the well-known gender patterns in the American workforce and the femaleness of contingent and part-time work.

Part 2 focuses on workplaces. It gives the countervailing human resource trends in the so-called 'family-sensitive firms' where contingent workers are typically ineligible for work-family programs (in Chapter 4 by Christensen) and questions whether contingent workers are really cost effective (in Chapter 5 by Nollen and Axel). The following chapter (by Drago), the only one based on non-U.S. data, examines the connection between contingent work and high performance practices, defined here as employee involvement practices. Chapter 7 (by Gonos) explores the interaction between market forces and government in the growth of contingent work through a case study of the temporary help industry and the temporary employment relationship it has promoted.

Part 3 examines how workers fare in contingent employment relationships by examining their economic, social, and psychological well-being. Chapter 8 (by Barker) brings the issue home through an analysis of the plight of adjunct professors as contingent workers. Chapter 9 
(by McAllister) shows how the highly educated workforce, discussed in the previous chapter, is not much different from the warehouse workers studied in this chapter. Chapter 10 (by Rebitzer) examines the job safety of contract workers - a much less studied factor - through a case study of the petrochemical industry.

Part 4 includes two chapters on policy, with Chapter 11 (by duRivage, Carré and Tilly) discussing labour law and part-time and contingent workers and Chapter 12 (by Carnevale, Jennings and Eisenmann) examining contingent workers within the employment law. Needless to say, both chapters argue that laws do not adequately cover contingent workers. In particular, the outdated concept of the employment relationship emerges as one of the hurdles to legal coverage. The last chapter of this volume (Chapter 13 by Barker and Christensen) provides summary findings and raises research questions.

The editors are to be congratulated for bringing researchers from a variety of disciplines to examine this important change in American employment relationships. I found each chapter in this book to be informative, providing answers to the questions editors proposed in the introductory chapter. However, each chapter seemed to stand alone without a clear identifying theme across chapters. The first chapter suggested an overall contextual analysis of the issues but such an analysis was not used in most other chapters. Moreover, the book is primarily on the 'bad jobs' of contingent work that the transitions in American workplaces have created. There are some, even if small in number, of 'good jobs' in temporary, self-employed contract and regular part-time work. It seems like the editors omitted these by choice, but explaining that fact - at least in the introductory chapter - could have contributed to the value of the book. Still, there was much to learn or to reaffirm existing knowledge in this book. I recommend it to researchers and practitioners interested in the topic of contingent work. For readers outside the U.S., the book also offers valuable information on the transformation in American employment relations.

ISIK URLA ZEYTINOGLU McMaster University

\section{Contracting Masculinity: Gender, Class and Race in a White-Collar Union, 1944-1994 \\ by Gillian CReESE, Don Mills, Ont.: Oxford University Press Canada, 1999, 279 p., ISBN 0-19-54154-3.}

Contracting Masculinity is a fascinating and provocative analysis of the role played by a trade union in structuring the workplace and the workforce. Gillian Creese effectively demonstrates that a union of office employees at British Columbia Hydro built and reinforced the segregation of "men's" and "women's" work in the practices it followed and, more importantly, in the contracts that it negotiated. Creese also is attentive to segregation by race, and reminds readers that the B.C. labour movement historically supported the exclusion of Asian workers. Until very recently, however, this particular union of clerical workers played little role, one way or another, in shaping the racist hiring practices of its employer. Contracting Masculinity therefore has much more to say about gender.

Creese has selected a very useful case study for her exploration of the gendered nature of trade union activity. Because of the feminization of some clerical work, between 40 to $55 \%$ of the workers within this white collar union were women. Creese therefore can very clearly compare their experiences with the men within the union, and few will 